\title{
Gonadotropin binding sites in eel ovary: Autoradiographic visualization and new data on specificity
}

\author{
C. SALMON, J. NUNEZ-RODRIGUEZ $\left({ }^{*}\right)$, J. MARCHELIDON, Françoise LE \\ MENN (*), Y. A. FONTAINE \\ Laboratoire de Physiologie Générale et Comparée, \\ Muséum National d'Histoire Naturelle, et Laboratoire d'Endocrinologie Comparée. \\ U.A. 90, C.N.R.S., 7, rue Cuvier, 75231 Paris Cedex 05. \\ ( ${ }^{*}$ Laboratoire de Biologie Marine, Institut de Biologie Animale, \\ Université de Bordeaux I, Avenue des Facultés, 33405 Talence Cedex.
}

Summary. An autoradiographic study of cGTH binding sites in eel ovary indicates that they were mainly located in the follicular layers. Eel ovary membranes exhibited specific ${ }^{125} \mathrm{I}-\mathrm{hCG}$ binding in vitro. In control fish we observed no cross-reaction between CGTH and hCG, whatever tracer hormone was used. On the contrary, carp pituitary extract (CPE) inhibited the binding of ${ }^{125}$-I-hCG as well as of ${ }^{125} /$-cGTH. These results show that a fish pituitary factor, different from the cGTH we used, had binding sites in the ovary. It is suggested that this factor might be an isoform of the gonadotropin. Lastly, we have shown in in vivo CPE-treated eels that $\mathrm{cGTH}$ and hCG cross-reacted, demonstrating that the receptor properties changed during $\mathrm{CPE}$-induced gonadal development.

\section{Introduction.}

The existence of saturable specific binding sites for carp gonadotropin (cGTH) in the silver eel (Anguilla anguilla) ovary was previously shown (Salmon et al., 1987). Binding was not significant in other eel organs. Scatchard analysis showed that the sites could be separated into two classes; one showed a low capacity and a high affinity and was thus compatible with the expected receptor properties. We describe here an attempt to localize these sites with an autoradiographic method.

Human chorionic gonadotropin (hCG) binding was also observed consistently. Earlier data on the stimulation of in vitro cyclic AMP (cAMP) production by eel ovary led us to hypothesize that several types of GTH receptors might exist in eel ovary (Salmon et al., 1985, 1986). In the present study, we further examined this hypothesis. The effects of an in vivo carp pituitary treatment on in vitro binding were also considered.

\section{Material and methods.}

Animals and in vivo treatments. - Silver eels weighing 240 to $650 \mathrm{~g}$ were captured in ponds (Etangs de la Somme, France). They were kept in large tanks in running tapwater and under natural photoperiod (February to March, 1987). Water temperature varied between 9 and $12^{\circ} \mathrm{C}$. 
In a first experiment, we used 3 control fish having a mean weight and gonadosomatic index (GSI) of $432 \pm 106 \mathrm{~g}$ and $1.8 \pm 0.1$, respectively.

In a second experiment, two groups of eels $(n=5)$ were injected i.p. three times a week for 2 months; control and treated eels received, respectively, $\mathrm{NaCl}$ $0.9 \%(0.5 \mathrm{ml} / 250 \mathrm{~g}$ of body weight) and carp pituitary extract (CPE : $0.25 \mathrm{mg}$ of dry pituitary $/ 0.5 \mathrm{ml} \mathrm{NaCl} 0.9 \% / 250 \mathrm{~g}$ of body weight). At the time of sacrifice, mean body weights and GSIs were $258 \pm 8 \mathrm{~g}$ and $1.8 \pm 0.2$ for the control group and $286 \pm 3 \mathrm{~g}$ and $4.8 \pm 0.4$ for the treated eels.

The fish were decapitated; the treated ones were killed 3 days after the last CPE injection. The ovaries were dissected, weighed for GSI determination and immediately frozen $\left(-20^{\circ} \mathrm{C}\right)$ until membrane preparation.

Hormones. - cGTH was prepared in collaboration with Dr Burzawa-Gérard according to Burzawa-Gérard (1971). Carp pituitary was extracted in $\mathrm{NaCl} 0.9 \%$ and diluted to $0.5 \mathrm{mg} / \mathrm{ml}$; its activity was then about $12.5 \mu \mathrm{g} \mathrm{cGTH} 6-178 / 0.5 \mathrm{ml}$ as assessed by stimulation of in vitro cAMP production by eel ovary (Fontaine-Bertrand et al., 1978). hCG (CR 121, about $13000 \mathrm{lU} / \mathrm{mg}$ ) was the kind gift of Dr Canfield (NIH).

Hormone radioiodination. - $\mathrm{cGTH}$ and $\mathrm{hCG}$ were radioiodinated as described previously (Salmon et al., 1987). Briefly, cGTH was labelled by the lactoperoxydase method according to Maghuin-Rogister et al. (1978). ${ }^{125}$ I-cGTH was purified by elution in Tris- $\mathrm{HCl} 10 \mathrm{mM}, \mathrm{pH} 7.4, \mathrm{NaN}_{3} 0.1 \%$ on a column $(18 \times 1.1 \mathrm{~cm})$ of Ultrogel AcA-54 (LKB); the most active fractions in the radioreceptor assay were pooled. Specific binding activity of the pool increased with membrane concentration and was about $10 \%$ of the total radioactivity in the presence of an excess membrane preparation (Salmon et al., 1987).

hCG was labelled with the lodogen method according to Salacinski et al. (1981). Labelled hCG was purified by elution in Tris- $\mathrm{HCl} 10 \mathrm{mM}, \mathrm{pH} 7.4$, $\mathrm{NaN}_{3} 0.1 \%$ on a column of Sephadex $\mathrm{G} 50(20 \mathrm{~cm}$ in a disposable $5-\mathrm{ml}$ pipette). The fraction containing the peak of radioactivity was used for hCG binding studies; its specific binding activity increased with membrane concentration and reached 20 to $30 \%$ of total radioactivity in the presence of excess membrane preparation (data not shown).

Autoradiography (from Lara and Droz, 1970; Bienarz and Kime, 1986). - One eel weighing $268 \mathrm{~g}$ was killed and its ovaries dissected ( $\mathrm{GSI}=1.73$ ). Pieces (about $50 \mathrm{mg}$ ) of ovaries were preincubated $20 \mathrm{~min}$ at $4{ }^{\circ} \mathrm{C}$ in $2 \mathrm{ml}$ of Krebs Ringer-Henseleit ( $\mathrm{KRB}$, half-concentration of $\mathrm{Ca}^{+{ }^{+}}$) then transferred to $2 \mathrm{ml}$ of fresh medium containing either labelled cGTH alone $\left(2 \times 10^{6} \mathrm{cpm}\right)$, for total binding (TB) determination, or labelled GTH plus $20 \mu \mathrm{g}$ of native GTH for non-specific binding (NSB) determination. Incubation lasted $3 \mathrm{~h}$, at the end of which the ovarian pieces were washed five times in cold KRB. They were then frozen on dry ice before being cut into $10-\mu \mathrm{m}$ sections with a cryostat at $-18{ }^{\circ} \mathrm{C}$. Sections were put on gelatined slides and dip-coated in Ilford K5 emulsion. After 2-month exposure, the autoradiographs were developed in D19 and counterstained with $2 \%$ toluidine blue. 
Membrane preparation. - Membranes were prepared as previously described (Salmon et al., 1987). Frozen ovaries were thawed then crushed with a press in one volume $(1 \mathrm{ml} / \mathrm{g}$ of fresh weight) of $\mathrm{KRB}$ containing aprotinin $(50 \mathrm{KIU} / \mathrm{ml})$. They were washed 6 times in the same buffer and transferred to one volume of Tris- $\mathrm{HCl} 10 \mathrm{mM}, \mathrm{pH} 7.4$, aprotinin $(50 \mathrm{KIU} / \mathrm{ml})$ for homogenization on ice in an Ultra-Turrax (maximal speed: $2 \times 10 \mathrm{sec}$ ). The homogenate was centrifuged $(1000 \times \mathrm{g})$ for $1 \mathrm{~min}$ at $4{ }^{\circ} \mathrm{C}$; the pellet and fat layer were discarded. The supernatant was filtered on nylon $(200 \mu \mathrm{m})$, then centrifuged $(23000 \times \mathrm{g})$ for $90 \mathrm{~min}$ at $4{ }^{\circ} \mathrm{C}$. The pellet was suspended in about one-tenth volume of Tris- $\mathrm{HCl}$ aprotinin and kept frozen at $-20^{\circ} \mathrm{C}$ overnight. After thawing, it was suspended in one to two volumes of Tris- $\mathrm{HCl}$ aprotinin and centrifuged $(5000 \times \mathrm{g})$ for 30 min at $4{ }^{\circ} \mathrm{C}$. The pellet was washed 5 to 6 times in the same conditions until the supernatant was clear. It was then suspended in Tris- $\mathrm{HCl} 10 \mathrm{mM}, \mathrm{pH} 7.4$, glycerol $5 \%$ ( $1 \mathrm{ml} / 10 \mathrm{~g}$ of ovary for control eels and $1 \mathrm{ml} / 40 \mathrm{~g}$ of ovary for treated eels) in order to obtain similar protein concentrations as assessed according to Bradford (1976).

Binding. - As previously described, in vitro binding was determined in low adsorption tubes (Minisorp, Nunc); ${ }^{125} \mathrm{I}-\mathrm{cGTH}$ binding to the tube was about $0.1 \%$ of total radioactivity. To $50 \mu \mathrm{l}$ of Tris- $\mathrm{HCl} 10 \mathrm{mM}, \mathrm{pH} 7.4, \mathrm{CaCl}_{2} 60 \mathrm{mM}$ were added $100 \mu$ l of Tris $\mathrm{HCl} 10 \mathrm{mM}$ either without cold hormone (TB), with an excess of it (NSB) (1 $\mu \mathrm{g}$ of $\mathrm{cGTH}$ or $10 \mu \mathrm{g}$ of $\mathrm{hCG}$ according to labelled hormone), or with an increasing dose of hormone (inhibition studies), $50 \mu$ l of radioactive hormone and $100 \mu \mathrm{l}$ of membrane suspension (0.1-0.15 $\mathrm{mg}$ of proteins). Incubation lasted $72 \mathrm{~h}$ at $4{ }^{\circ} \mathrm{C}$ and was terminated by dilution in $2 \mathrm{ml}$ of cold Tris- $\mathrm{HCl} 10 \mathrm{mM}, \mathrm{pH} 7.4$, and centrifugation $(10000 \times \mathrm{g})$ for $10 \mathrm{~min}$ at $4{ }^{\circ} \mathrm{C}$; the supernatant was discarded and pellet radioactivity was measured in a multiwell gamma counter. Specific binding (SB) was the difference between TB and NSB and was expressed as a percentage of total radioactivity.

\section{Results.}

Autoradiography. - The autoradiographic visualization of ${ }^{125} \mid-c G T H$ binding in control eels is presented in figures 1 (TB) and 2 (NSB); in each figure, part (a) (dark field) shows the distribution of silver grains while part (b) (normal light) shows the ovarian structures. In TB, the silver grains were concentrated around the oocytes; in NSB, the sections were uniformly labelled with a low-grain density. This suggests that the particular localization of the grains in TB was related to specific $\mathrm{CGTH}$ binding. A comparison with the structures indicates that the silver grains in TB were associated with follicular layers.

In vitro binding of ${ }^{125} /-c G T H$ and ${ }^{125}$ /- hCG to untreated ee/ ovary membranes (experiment I). - Untreated eel ovary membrane bound labelled cGTH and hCG (fig. 3). SB was 4 and $2 \%$, respectively, of total radioactivity. ${ }^{125}$ I-cGTH SB was inhibited by increasing doses of $\mathrm{cGTH}$ but not by hCG, even at high concentrations (fig. 3, upper part) ; bound ${ }^{125}$-hCG was displaced by hCG, but 


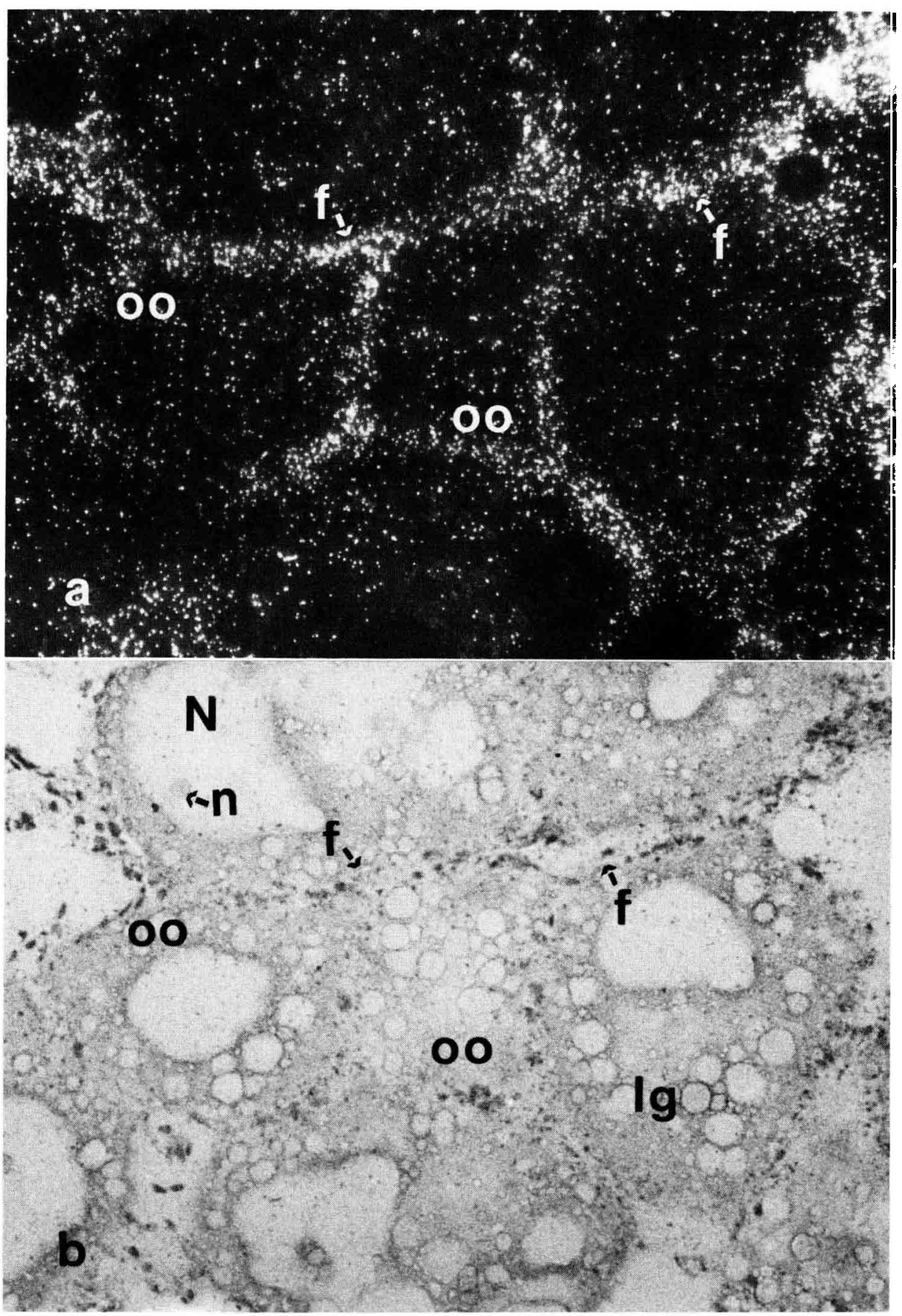

FIG. 1. - Autoradiograph of control eel ovary section. a : Total binding of ${ }^{125} \mid$-cGTH observed in dark field conditions. $b$ : Same section observed in normal light conditions. $f$ : follicle, Ig: lipidic globule, $N$ : nucleus, $n$ : nucleolus, oo: oocyte. $(\times 250)$. 

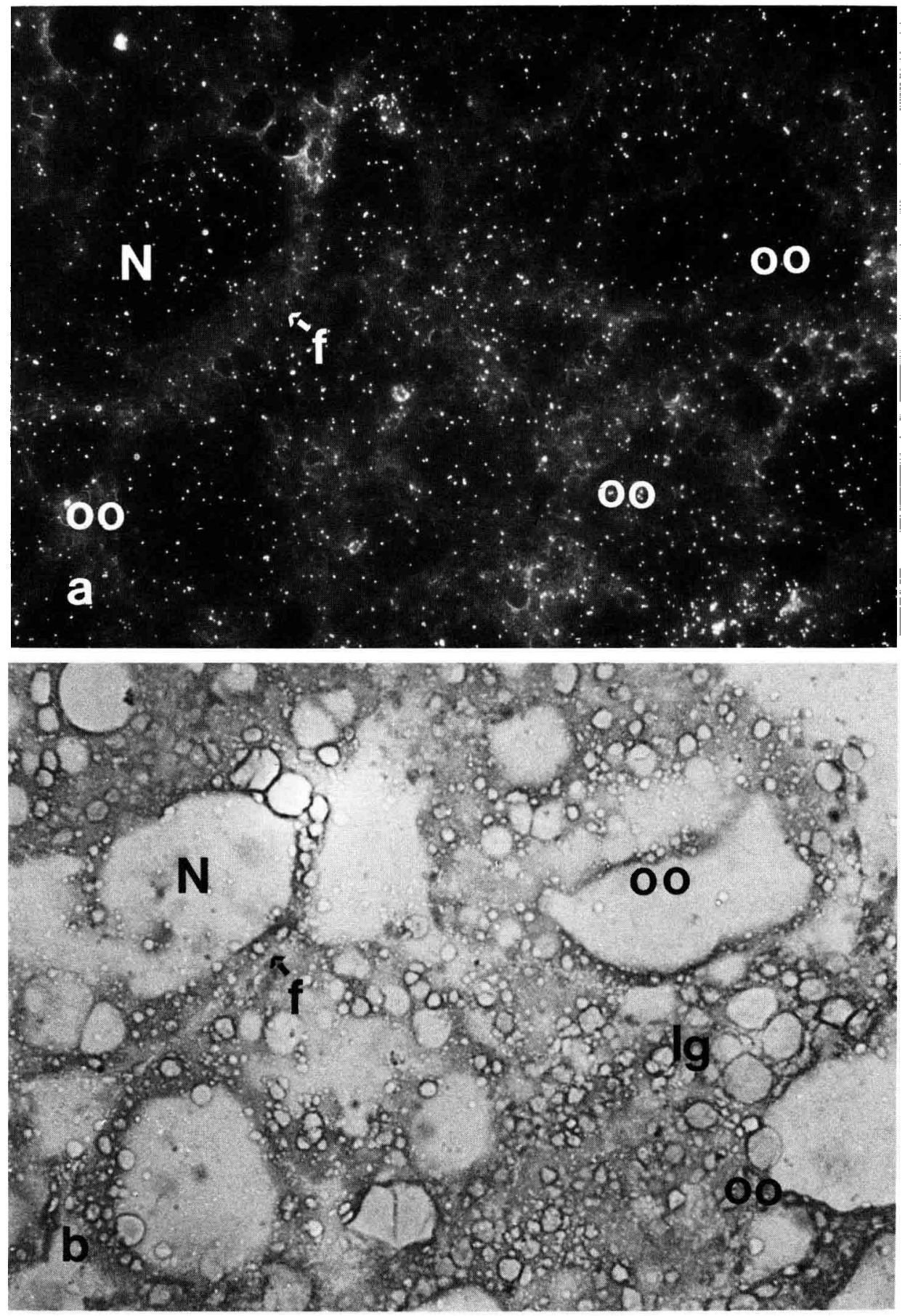

FIG. 2. - Autoradiograph of control eel ovary section. a : Binding of ${ }^{125} /$-cGTH in presence of $20 \mu \mathrm{g} \mathrm{cGTH}$ observed in dark field conditions. b : Same section in normal light conditions. For abbreviations, see figure $1 .(\times 250)$. 
not by $\mathrm{CGTH}$, even at high concentrations (fig. 3, lower part). A $50 \%$ inhibition of labelled hormone SB was obtained between 9 and $27 \mathrm{ng}$ of $\mathrm{cGTH} /$ tube for ${ }^{125} \mathrm{I}-\mathrm{cGTH}$ and between 243 and $729 \mathrm{ng}$ of hCG/tube for ${ }^{125} \mathrm{I}-\mathrm{hCG}$.

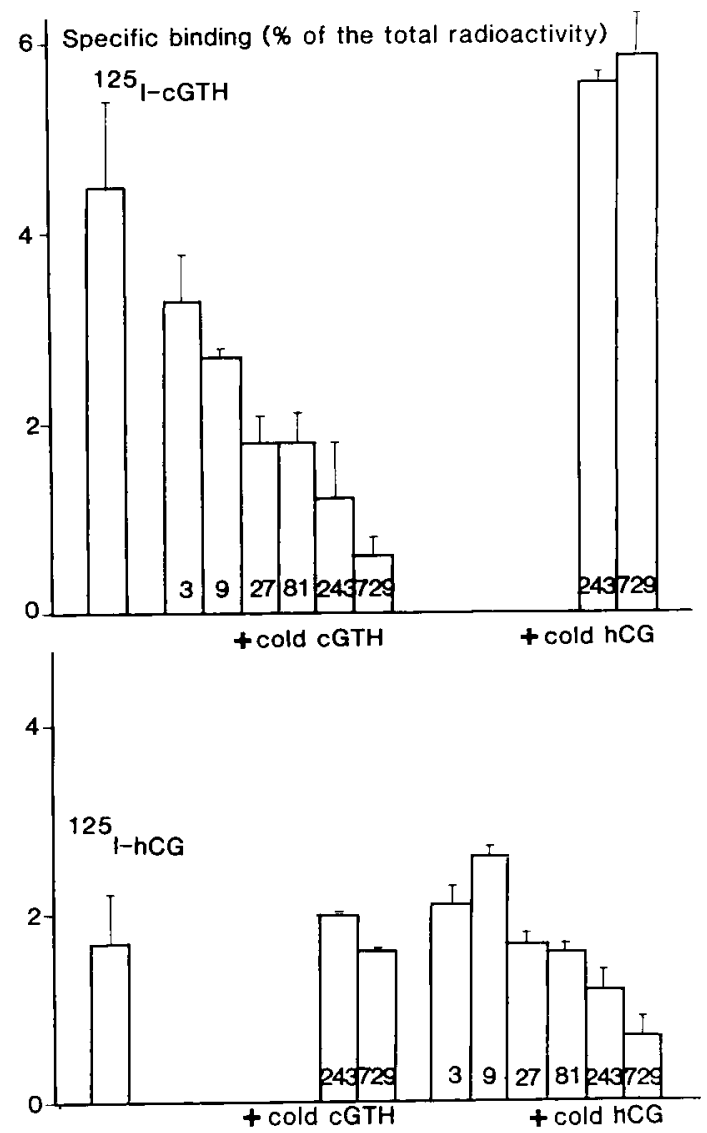

FIG. 3. - Specific binding of ${ }^{125} /$-cGTH and ${ }^{125} /$ - hCG to ovarian membranes of untreated silver ee/s (experiment l). Total radioactivity: $27000 \mathrm{cpm} /$ tube. Unlabelled hormone concentrations : $\mathrm{ng} /$ tube. Values are the means of two incubations (vertical lines: range between the two determinations).

Effects of in vivo carp pituitary treatment on in vitro $c G T H$ and hCG binding (experiment II). - Figure 4 shows that labelled hormones exhibited the same binding behaviour in the control group of experiment II as in normal eels studied in experiment I. Again, no cross-reaction was observed between cGTH and hCG. Surprisingly, SB of both labelled hormones was inhibited by carp pituitary extract; this inhibition was dose-dependent with ${ }^{125}$-cGTH as tracer, while it was maximal with the lowest dose of CPE in the case of ${ }^{125} \mathrm{I}-\mathrm{hCG}$. 


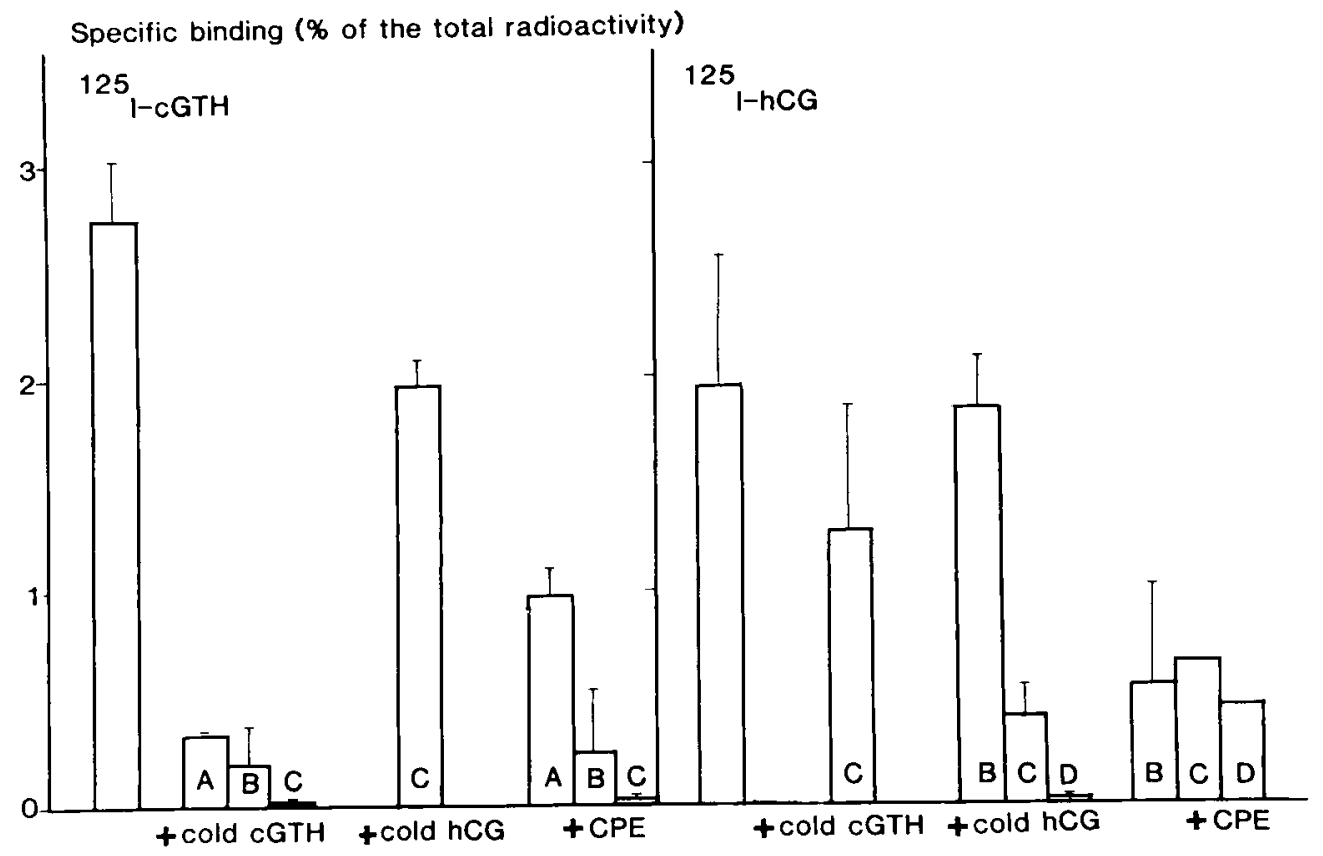

FIG. 4. - Specific binding of $125 /-$ - GTH and $125 /-h C G$ to ovarian membranes of control ee/s (experiment (I). Total radioactivity : $37000 \mathrm{cpm}$. Unlabelled hormone concentration (ng/tube) : $\mathrm{A}=9, \mathrm{~B}=81, \mathrm{C}=729, \mathrm{D}=6560$. CPE concentration is expressed as CGTH equivalent. Values are the means of two incubations (vertical lines: range between the two determinations).

In vivo treatment with CPE induced an important change in binding properties in vitro (fig. 5). hCG became able to completely inhibit ${ }^{125}$-cGTH SB, and CGTH could displace at least part of the bound ${ }^{125}$ I-hCG. CPE kept the ability to inhibit the binding of mammalian and fish hormones; this inhibition needed higher doses for ${ }^{125}$-hCG than for ${ }^{125}$ - - CGTH.

\section{Discussion.}

The presence of gonadotropin binding sites in fish ovary is now increasingly documented (Van der Kraak, 1983 ; Salmon et al., 1984 ; Breton et al., 1986 ; Salmon et al., 1987 ; Jamal Uddin and Bhattacharya, 1987 ; Kanamori et al., 1987). Their specificity and biochemical properties are usually considered as evidence of their ability to be the GTH receptors. If so, they are supposed to stay mainly in the somatic cells of the follicle. In the present paper, we describe an attempt at autoradiographic visualization of cGTH specific binding. Radioactive hormone seems mainly associated with the follicular layers, although it is impossible to determine whether any of the layers are more concerned than 




FIG. 5. - Specific binding of ${ }^{125 /-c G T H}$ and ${ }^{125 /-h C G}$ to ovarian membranes of CPE treated eels (experiment /I). Total radioactivity: $37000 \mathrm{cpm}$. Unlabelled hormone concentration (ng/tube) : $\mathrm{A}=9, \mathrm{~B}=81, \mathrm{C}=729, \mathrm{D}=6560$. CPE concentration is expressed as cGTH equivalent. Values are the means of two incubations (vertical lines : range between the two determinations).

others; inner oocyte structures are more lightly labelled. Furthermore, only the peripheral silver grains disappeared when the tissue was incubated with excess cGTH, demonstrating cGTH specific binding in follicular layers. This result is in agreement with the work of Bienarz and Kime (1986) on common carp ovary.

We observed that a mammalian GTH, namely human chorionic gonadotropin, was able to bind to control eel ovary membranes and could not be displaced by cGTH. The inhibition of hCG SB by hCG needs about 30 times more cold hormone than does CGTH SB inhibition by CGTH. CPE inhibits both ${ }^{125} \mathrm{I}$-cGTH and ${ }^{125} /$-hCG, even though inhibition seems to be less complete and needs higher CPE doses in the case of ${ }^{125} \mathrm{I}-\mathrm{hCG}$. This, and the high unlabelled hCG doses needed to inhibit hCG SB, may be related to the lower reversibility of hCG specific binding. As previously noted, hCG cannot displace bound labelled cGTH (Salmon et al., 1987). Schulz et al. (1985) and Jamal Uddin and Bhattacharya (1987) also described hCG binding to ovarian membranes of previtellogenic or vitellogenic trout and mature murrel, respectively. In murrel, hCG (or ovine LH) could not displace more than $10 \%$ of the bound fish GTH.

Former data on in vitro stimulation of cAMP production by eel ovary suggest that ovine LH and hCG interact with part of the cGTH receptor pool in eel ovary (Salmon et al., 1985, 1986). In these conditions there should be a cross-reaction 
between cGTH and hCG. Its absence indicates that the binding sites for these hormones are likely to be different. This raises the question of the physiological meaning of hCG SB to a fish gonad. There may be some similarity between hCG and a fish hormone, such as a second gonadotropin (Idler et al., 1975a, 1975b; Kawauchi et al., 1986) or another factor controlling some gonadal function. There is strong evidence supporting the unicity of gonadotropin in fish (for review, see Fontaine, 1985) and it seems unlikely that an unrelated GTH receptor would bind hCG. Gonadotropin isoforms exist in mammals (e.g. Chappel et al., 1983, 1985 ; Blum et al., 1985 ; Matteri et al., 1986) as well as in fish (Huang et al., 1981 ; Goncharov et al., 1983 ; Kuznetzov et al., 1983 ; Swanson et al., 1987). A general consensus is that isoforms are coded by the same gene but are differently processed (e.g. with regard to glycosylation). These isohormones may differ in their biological activities (Goncharov et al., 1983) and may be dependent on the hormonal state of the organism (e.g. Chappel et al., 1985) ; thus, they could play a role in the fine regulation of the gonadal functions. We suggest that isoform-specific GTH isoreceptors may exist in the gonad. From this viewpoint, the present demonstration of the dual activity of CPE in inhibiting both ${ }^{125} /$-CGTH and ${ }^{125} /$-hCG binding is of interest; it shows that the specific hCG binding site of eel ovary interacts with a pituitary factor, likely to be an isoform of cGTH and absent from the preparations we used. Indeed, several isohormones with their own isoreceptors should be functionally equivalent to a plurihormonal system, at least during the physiological stages when receptors are highly specific ; gonadal regulation by pituitary hormones should then result from the differential processing of a single gene product instead of from the productions of two different genes.

Developmental influences on binding specificity have been assessed after a CPE treatment in vivo which induces vitellogenesis in eel. After 2 months, we observed an important shift in the binding site properties; as in control eels, the inhibition of ${ }^{125} /$-hCG binding required higher cold hormone or CPE doses than did ${ }^{125} \mathrm{I}-\mathrm{cGTH}$, but $\mathrm{hCG}$ and $\mathrm{cGTH}$ could cross-react, whatever the tracer hormone was. This means that the binding sites and/or their membrane environment were modified according to the gonadal stage.

Reçu en octobre 1987 Accepté en avril 1988.

Acknowledgements. - This work was supported by a grant from I.N.R.A. (A.T.P. "Hormones hypophysaires et fonction de reproduction chez les Vertébrés »). The authors thank DrR. Canfield for the kind gift of hCG.

Résumé. Sites de liaison des gonadotropines dans l'ovaire d'anguille: visualisation autoradiographique et nouvelles données sur leur spécificité.

Une étude autoradiographique des sites de liaison de la cGTH dans l'ovaire d'anguille argentée indique qu'ils sont situés essentiellement dans les couches folliculaires.

In vitro, des préparations membranaires d'ovaire d'anguille contiennent aussi des sites de liaison de la hCG, spécifiques de cette hormone. Nous n'observons pas, chez les témoins, de réaction croisée entre la cGTH et la hCG quelle que soit l'hormone marquée 
utilisée. Par contre, un extrait d'hypophyse de carpe (CPE) inhibe la liaison non seulement de la ${ }^{125} \mid$-cGTH mais aussi de la ${ }^{125}$-I-hCG. Ce résultat montre qu'un facteur présent dans l'hypophyse de poisson, différent de la cGTH utilisée dans cette expérience, possède des sites de liaison dans l'ovaire. Nous suggérons qu'il peut s'agir d'une isoforme de la gonadotropine.

Enfin, nous montrons que, pendant la vitellogenèse induite par un traitement avec CPE in vivo, cGTH et hCG acquièrent la capacité de faire des réactions croisées. Ceci montre que les propriétés des récepteurs changent pendant la maturation de la gonade.

\section{References}

BIENARK Z., KIME D. E., 1986. Autoradiographic localization of gonadotrophin receptors in ovaries of the common carp, Cyprinus carpio L. Gen. comp. Endocrinol., 64, 151-156.

BLUM W. F. P., RIEGELBAUER G., GUPTA D., 1985. Heterogeneity of rat FSH by chromatofocusing : studies of in vitro bioactivity of pituitary FSH forms and effect of neuraminidase treatment. J. Endocr., 105, 17-27.

BRADFORD M. M., 1976. A rapid and sensitive method for the quantitation of microgram quantities of protein utilizing the principle of protein-dye binding. Anal. Biochem., 72, 248-254.

BRETON B., LE GAC F., SAMBRONI E., 1986. Gonadotropin hormone (GTH) receptors in the ovary of the brown trout Salmo trutta L. in vitro studies. Gen. comp. Endocrinol., 64, 163-171.

BURZAWA-GÉRARD E., 1971. Purification d'une hormone gonadotrope hypophysaire de poisson téléostéen, la carpe (Cyprinus carpio L.). Biochimie, 53, 545-552.

CHAPPEL S. C., BETHEA C. L., SPIES H. G., 1985. Existence of multiple forms of folliclestimulating hormone within the anterior pituitaries of Cynomolgus monkeys. Endocrinology, $115,452-461$.

CHAPPEL S. C., ULLUA-AGUIRRE A., COUTIFARIS C., 1983. Biosynthesis and secretion of follicle-stimulating hormone. Endoc. Rev., 4, 179-211.

FONTAINE Y. A., 1985. Hormonal peptide evolution, 413-432. In FOREMAN R. E., GORBMAN A., DODD J. M., OLSSON R., Evolutionary biology of primitive fishes. Plenum Press, New York and London.

FONTAINE-BERTRAND E., SALMON C., FONTAINE Y. A., 1978. Effets d'hormones gonadotropes in vitro sur la concentration de l'adénosine monophosphate cyclique dans l'ovaire d'anguille (Anguilla anguilla L.). Ann. Biol. anim. Biochim. Biophys., 18, 805-811.

GONCHAROV B. F., KUZNETZOV A. A., BURZAWA-GÉRARD E., 1983. Pituitary gonadotropic hormone from a chondrostean fish, starred sturgeon (Acipenser stellatus Pall.). IV. Differences in biological actions of isoforms and absence of sex specific forms. Gen. comp. Endocrinol., 49, 375-382.

HUANG F. L., HUANG C. J., LIN S. H., LO T. B., PAPKOFF H., 1981. Isolation and characterization of gonadotropin isohormones from pituitary gland of pike eel (Muraenesox cinereus). Int. J. Peptide Protein Res., 18, 69-78.

IDLER D. R., BAZAR L. S., HWANG S. J., 1975a. Fish gonadotropin(s). II. Isolation of gonadotropin(s) from chum salmon pituitary glands using affinity chromatography. Endoc. Res. Commun., 2, 215-235.

IDLER D. R., BAZAR L. S., HWANG S. J., 1975b. Fish gonadotropin(s). III. Evidence for more than one gonadotropin in chum salmon pituitary glands. Endoc. Res. Commun., 2, 237-249.

JAMAL UDDIN Md., BHATTACHARYA S., 1987. In vitro binding of gonadotrophin to fish ovary. J. Endocr., 111, 407-413.

KANAMORI A., KAGAWA H., NAGAHAMA Y., 1987. Gonadotropin receptors in the postovulatory ovary of amago salmon (Oncorhynchus rhodurus). Gen. comp. Endoc., 66, 210-217.

KAWAUCHI H., SUZUKI K., NAGAHAMA Y., ADACHI S., NAITO N., NAKAI Y., 1986. Occurrence of two distincts gonadotropins in chum salmon pituitary, 383-390. In YOSHIMURA F., GORBMANA., Pars distalis of the pituitary gland: structure, function and regulation. Elsevier Science. 
KUZNETZOV A. A., GONCHAROV B. F., BURZAWA-GÉRARD E., 1983. Pituitary gonadotropic hormone from a chondrostean fish, starred sturgeon (Acipenser stellatus Pall.). III. Polymorphism. Gen. comp. Endocrinol., 49, 364-374.

LARA F., DROZ B., 1970. Techniques autoradiographiques et leurs applications à l'étude du renouvellement des constituants cellulaires. J. Microscopie, 9, 845-879.

MAGHUIN-ROGISTER G., CLOSSET J., COMBARNOUS Y., HENNEN G., DECHENNE C., KETELSLEGER J. M., 1978. Study of follitropin receptor in testis using a homologous system. Binding of porcine follitropin to plasma membrane from immature porcine testis and correlation with adenylate cyclase stimulation. Eur. J. Biochem. 86, 121-131.

MATTERI R. L., PAPKOFF H., NG D. A., SWEDLOW J. R., CHANG Y. S., 1986. Isolation and characterization of three forms of luteinizing hormone from the pituitary gland of the horse. Biol. Reprod., 43, 571-578.

SALACINSKI P. R. P., MCLEAN C., SYKES J. E. C., CLEMENT-JONES V. V., LOWRY P. J., 1981. Iodination of proteins, glycoproteins and peptides using a solid-phase oxidizing agent, 1,3,4,6-tetrachloro-3-6-diphenyl glycoluryl (lodogen). Anal. Biochem., 117, 136-146.

SALMON C., KAGAWA H., ADACHI S., NAGAHAMA Y., FONTAINE Y. A., 1984. Mise en évidence de sites de liaison spécifique de la gonadotropine de Saumon chum (Oncorhynchus keta) sur des préparations membranaires d'ovaire de Saumon amago (Oncorhynchus rhodurus). C.R. Acad. Sci. (Paris), Sér. III, 298, 337-340.

SALMON C., MARCHELIDON J., FONTAINE-BERTRAND E., FONTAINE Y. A., 1985. Human chorionic gonadotropin and immature fish ovary : characterization and mechanism of the in vitro stimulation of cyclic adenosine monophosphate accumulation. Gen. comp. Endocrinol., 58, $101-108$.

SALMON C., MARCHELIDON J., FONTAINE-BERTRAND E., FONTAINE Y. A., 1986. Accumulation du monophosphate cyclique d'adénosine dans l'ovaire d'anguille (Anguilla anguilla) in vitro sous l'effet de la gonadotropine de carpe ou de la lutropine ovine: Cinétique et thermodépendance. Reprod. Nutr. Dévelop., 26, 429-439.

SALMON C., MIYASHITA Y., MARCHELIDON J., FONTAINE Y. A., 1987. Mise en évidence et propriétés des sites de liaison spécifique pour la gonadotropine de carpe dans des préparations membranaires d'ovaire d'Anguille (Anguilla anguilla L.). Gen. comp. Endocrinol., 65, 203-211.

SCHULZ R., SCHLAGHECKE R., BLUM V., 1985. A particulate membrane preparation from ovaries of preovulatory rainbow trout (Salmo gairdneri) : Binding studies with ${ }^{125} 1$-human chorionic gonadotropin. Comp. Biochem. Physiol. A, 82, 429-433.

SWANSON P., DICKHOFF W. W., GORBMAN A., 1987. Pituitary thyrotropin and gonadotropin of coho salmon (Oncorhynchus kisutch): separation by chromatofocusing. Gen. comp. Endocrinol., 65, 269-287.

VAN DER KRAAK G., 1983. An introduction to gonadotropin receptor studies in fish, 405-441. In HOAR W. M., RANDALL D. J., DONALDSON E. M., Fish physiology, Vol. 9A, Acad. Press, New York. 